\title{
Recruitment sex ratios in gray-tailed voles (Microtus canicaudus) in response to density, sex ratio, and season.
}

\author{
Bond, M L ; Wolff, J O ; Krackow, S
}

\begin{abstract}
We tested predictions associated with three widely used hypotheses for facultative sex-ratio adjustment of vertebrates using eight enclosed populations of gray-tailed voles, Microtus canicaudus. These were (i) the population sex ratio hypothesis, which predicts that recruitment sex ratios should oppose adult sex-ratio skews, (ii) the local resource competition hypothesis, which predicts female-biased recruitment at low adult population density and male-biased recruitment at high population density, and (iii) the first cohort advantage hypothesis, which predicts that recruitment sex ratios should be female biased in the spring and male biased in the autumn. We monitored naturally increasing population densities with approximately equal adult sex ratios through the spring and summer and manipulated adult sex ratios in the autumn and measured subsequent sex ratios of recruits. We did not observe any significant sex-ratio adjustment in response to adult sex ratio or high population density; we did detect an influence of time within the breeding season, with more female offspring observed in the spring and more male offspring observed in the autumn. Significant seasonal increases in recruitment sex ratios indicate the capacity of female gray-tailed voles to manipulate their offspring sex ratios and suggest seasonal variation in the relative reproductive value of male and female offspring to be a regular phenomenon. Résumé : Nous avons vérifié les prédictions associées à trois hypothèses couramment utilisées pour expliquer l'ajustement facultatif des rapports mâles:femelles des mammifères chez huit populations en enclos du campagnol à queue grise, Microtus canicaudus. Les trois hypothèses sont (i) l'hypothèse du rapport mâles:femelles de la population qui prédit que les rapports mâles:femelles dans la progéniture devraient rectifier les anomalies dans le rapport mâles: femelles des adultes, (ii) l'hypothèse de la compétition pour les ressources locales qui prédit un recrutement surtout de femelles lorsque les densités de populations d'adultes sont faibles et un recrutement surtout de mâles aux fortes densités et (iii) l'hypothèse de l'avantage de la première cohorte qui prédit que le rapport mâles:femelles dans le recrutement devrait favoriser les femelles au printemps et les mâles à l'automne. Nous avons suivi la croissance naturelle des densités de populations avec des rapports mâles:femelles à peu près égaux à 1 chez les adultes durant le printemps et l'été; à l'automne, nous avons manipulé les rapports mâles:femelles des adultes et mesuré les rapports mâles:femelles qui ont prévalu dans le recrutement. Nous n'avons pas observé d'ajustement significatif du rapport mâles:femelles en réaction au rapport mâles:femelles des adultes, ni à la forte densité de la population. Nous avons cependant détecté un effet du moment de la saison de la reproduction, avec plus de femelles parmi les petits au printemps et plus de mâles à l'automne. Des accroissements saisonniers significatifs du rapport mâles:femelles dans le recrutement indiquent que les campagnols à queue grise sont capables de manipuler le rapport mâles:femelles de leur descendance. Cela laisse croire que la variation saisonnière de la valeur reproductive relative des descendants mâles et femelles est un phénomène régulier. [Traduit par la Rédaction]
\end{abstract}

DOI: https://doi.org/10.1139/Z03-116 
ZORA URL: https://doi.org/10.5167/uzh-462

Journal Article

Published Version

Originally published at:

Bond, M L; Wolff, J O; Krackow, S (2003). Recruitment sex ratios in gray-tailed voles (Microtus canicaudus) in response to density, sex ratio, and season. Canadian Journal of Zoology, 81(8):1306-1311.

DOI: https://doi.org/10.1139/Z03-116 


\title{
Recruitment sex ratios in gray-tailed voles (Microtus canicaudus) in response to density, sex ratio, and season
}

\author{
Monica L. Bond, Jerry O. Wolff, and Sven Krackow
}

\begin{abstract}
We tested predictions associated with three widely used hypotheses for facultative sex-ratio adjustment of vertebrates using eight enclosed populations of gray-tailed voles, Microtus canicaudus. These were (i) the population sex ratio hypothesis, which predicts that recruitment sex ratios should oppose adult sex-ratio skews, (ii) the local resource competition hypothesis, which predicts female-biased recruitment at low adult population density and malebiased recruitment at high population density, and (iii) the first cohort advantage hypothesis, which predicts that recruitment sex ratios should be female biased in the spring and male biased in the autumn. We monitored naturally increasing population densities with approximately equal adult sex ratios through the spring and summer and manipulated adult sex ratios in the autumn and measured subsequent sex ratios of recruits. We did not observe any significant sexratio adjustment in response to adult sex ratio or high population density; we did detect an influence of time within the breeding season, with more female offspring observed in the spring and more male offspring observed in the autumn. Significant seasonal increases in recruitment sex ratios indicate the capacity of female gray-tailed voles to manipulate their offspring sex ratios and suggest seasonal variation in the relative reproductive value of male and female offspring to be a regular phenomenon.
\end{abstract}

Résumé : Nous avons vérifié les prédictions associées à trois hypothèses couramment utilisées pour expliquer l'ajustement facultatif des rapports mâles:femelles des mammifères chez huit populations en enclos du campagnol à queue grise, Microtus canicaudus. Les trois hypothèses sont (i) l'hypothèse du rapport mâles:femelles de la population qui prédit que les rapports mâles:femelles dans la progéniture devraient rectifier les anomalies dans le rapport mâles: femelles des adultes, (ii) l'hypothèse de la compétition pour les ressources locales qui prédit un recrutement surtout de femelles lorsque les densités de populations d'adultes sont faibles et un recrutement surtout de mâles aux fortes densités et (iii) l'hypothèse de l'avantage de la première cohorte qui prédit que le rapport mâles:femelles dans le recrutement devrait favoriser les femelles au printemps et les mâles à l'automne. Nous avons suivi la croissance naturelle des densités de populations avec des rapports mâles:femelles à peu près égaux à 1 chez les adultes durant le printemps et l'été; à l'automne, nous avons manipulé les rapports mâles:femelles des adultes et mesuré les rapports mâles:femelles qui ont prévalu dans le recrutement. Nous n'avons pas observé d'ajustement significatif du rapport mâles:femelles en réaction au rapport mâles:femelles des adultes, ni à la forte densité de la population. Nous avons cependant détecté un effet du moment de la saison de la reproduction, avec plus de femelles parmi les petits au printemps et plus de mâles à l'automne. Des accroissements saisonniers significatifs du rapport mâles:femelles dans le recrutement indiquent que les campagnols à queue grise sont capables de manipuler le rapport mâles:femelles de leur descendance. Cela laisse croire que la variation saisonnière de la valeur reproductive relative des descendants mâles et femelles est un phénomène régulier.

[Traduit par la Rédaction]

\section{Introduction}

Sex-ratio theory predicts that female mammals can maximize their fitness by investing equally in sons and daughters when the reproductive return of each sex is equal, or by facultatively adjusting the sex ratio of their offspring if the reproductive return of one sex is greater than that of the other (e.g., Fisher 1930; Hamilton 1967; Trivers and Willard
1973; Frank 1990; Pen et al. 1999; Pen and Weissing 2002). For instance, if individual mothers differ in their investment ability and the sexes differ in their reproductive potential as a result of that investment, adjustment of individual offspring sex ratios can be adaptive under some circumstances (Trivers and Willard 1973; Leimar 1996) such as in response to differences in local resource competition levels (e.g., Clark 1978; van Schaik and Hrdy 1991; Hewison and

Received 29 October 2002. Accepted 6 June 2003. Published on the NRC Research Press Web site at http://cjz.nrc.ca on 29 August 2003.

M.L. Bond. ${ }^{1}$ Department of Fisheries and Wildlife, Oregon State University, Corvallis, OR 97331, U.S.A.

J.O. Wolff. Department of Biology, University of Memphis, Memphis, TN 38152, U.S.A.

S. Krackow. Verhaltensbiologie, Zoologisches Institut, Universität Zurich-Irchel, CH-8057 Zurich, Switzerland.

${ }^{1}$ Corresponding author (e-mail: mbond@biologicaldiversity.org). 
Gaillard 1996) as well as in local adult sex ratios (e.g., Bensch et al. 1999; Ranta et al. 2000). In this study, we tested the predictions of three hypotheses for facultative sexratio adjustment.

The population sex ratio (PSR) hypothesis predicts that if adult sex ratios are biased, females should skew the sex ratio of their offspring to produce the rarer sex. Counterbalancing skews in adult sex ratios should have adaptive value, as each individual of the underrepresented sex has a frequencydependent mating advantage and will contribute proportionally more genes to succeeding generations than the more common sex (sensu Bensch et al. 1999; Ranta et al. 2000). Some evidence to support this hypothesis has been found in house mice, Mus musculus (Sadler 1981), and female snow skinks, Niveoscincus microlepidotus (Olsson and Shine 2001), in which females produced more offspring of the sex that was rarer in the adult population.

The local resource competition (LRC) hypothesis predicts that if resources are abundant in and around the maternal home range, females should produce more of the sex of the offspring that is philopatric and can take advantage of these resources; in mammals, this is usually female. Conversely, if competition is intense in the natal home-range area, females should produce the dispersing sex, typically males, which would suffer less from local competition than the philopatric sex. Observational evidence for this hypothesis has been demonstrated in Townsend's voles, Microtus townsendii (Lambin 1994), lions, Felis leo (Packer and Pusey 1987), and several species of primates (Clark 1978; Silk 1983; van Schaik and Hrdy 1991).

The first cohort advantage (FCA) hypothesis predicts that if resource availability fluctuates over the breeding season, or if any behavioral or ecological factor is more advantageous for one sex than for the other, females might adjust offspring sex ratio accordingly (sensu Werren and Charnov 1978; Lambin 1994). For instance, several species of voles appear to produce more daughters in spring and sons in autumn (McShea and Madison 1986; Boonstra 1989; Saitoh 1990; Lambin 1994; Wright et al. 1995). Apparently, springborn females can breed earlier and more successfully than spring-born males; in contrast, males have higher overwinter survival and higher reproductive success the following spring (McShea and Madison 1986). Therefore, mothers might adjust the sex ratio of their offspring to favor daughters in spring and sons in autumn.

Although strong theoretical arguments with some supportive evidence are available for the adaptive significance of facultative sex-ratio adjustments, few experimental studies have been conducted in the laboratory and none have been conducted in the field to test these predictions. The objective of our study was to test the above three hypotheses for facultative sex-ratio adjustment. To test these hypotheses, we monitored naturally increasing population densities and varying adult sex ratios through the spring and summer and manipulated adult sex ratios in the autumn of eight enclosed populations of gray-tailed voles, Microtus canicaudus, and measured the sex of recruits. Gray-tailed voles are herbivorous grassland rodents exhibiting a promiscuous mating system, females are territorial with respect to other females (Bond and Wolff 1999), females are more philopatric than males (Dalton 2000), and the breeding season extends from early March to late December (Wolff et al. 1994). The gestation period is 21 days and development is rapid, with recently weaned females sometimes breeding at 18 days of age, and generations are highly overlapping (Wolff et al. 1994). Therefore, gray-tailed voles appear to represent a model species with which to test the above hypotheses.

\section{Methods}

\section{Study site}

The experiment was conducted at Oregon State University's Hyslop Agronomy Farm, $10 \mathrm{~km}$ north of Corvallis, Oregon. The experimental units consisted of eight 0.2-ha $(45 \mathrm{~m} \times 45 \mathrm{~m})$ enclosures planted with several species of grass. The enclosures were constructed of sheet metal $90 \mathrm{~cm}$ high and buried $90 \mathrm{~cm}$ deep to contain the voles, and a $1-\mathrm{m}$ strip was mowed bare along the inside of the fences to minimize its use by voles. In each enclosure, nine rows of nine trap stations were spaced $5 \mathrm{~m}$ apart for a total of 81 stations, with one Sherman live trap at each station.

\section{Experimental procedures}

Six adult male and six adult female voles were placed into each of the eight enclosures at the beginning of May 1997 and population densities were allowed to increase until September 1997 (18 weeks). In late September, one of two sexratio treatments was randomly allocated to each of the eight enclosures, providing four replicates of each treatment. Population sex ratios were manipulated towards either high densities of adult males and low densities of adult females or low densities of adult males and high densities of adult females. To initiate the sex-ratio experiment, females and males were removed from or added to previous populations such that remaining animals were evenly spaced throughout each enclosure to maximize random mating.

\section{Capture-mark-recapture}

Vole populations were monitored using standard capturemark-recapture techniques. Voles were livetrapped for 4 consecutive days at 2-week intervals from early May until late December for a total of 8 months. Traps were baited with oats and sunflower seeds and either set in the evening and checked at sunrise or set before sunrise and checked at midday, depending on the ambient temperature. All animals were ear-tagged for identification, and data recorded for each trapped animal included body mass (to the nearest gram), sex, trap location, and reproductive condition of females. Females were considered to be in reproductive condition if they were pregnant or lactating. Voles were classified as juveniles $(<30 \mathrm{~g})$ or adults $(\geq 30 \mathrm{~g})$, and any newly captured, untagged animals were considered recruits born into the population. All newly captured animals were ear-tagged and left in the enclosures throughout the summer to allow population densities to increase but were removed from the sex-ratio treatment enclosures to maintain skewed sex ratios and control densities. The voles were cared for in accordance with the principles and guidelines of the American Society of Mammalogists.

Population size and sex ratio of adults were calculated for each trap week throughout the entire study period using minimum number known alive (Myers and Krebs 1971). 
Fig. 1. Population size of adult gray-tailed voles, Microtus canicaudus, measured at 2-week intervals in eight enclosures from spring through autumn at Hyslop Farm, Oregon, 1997.

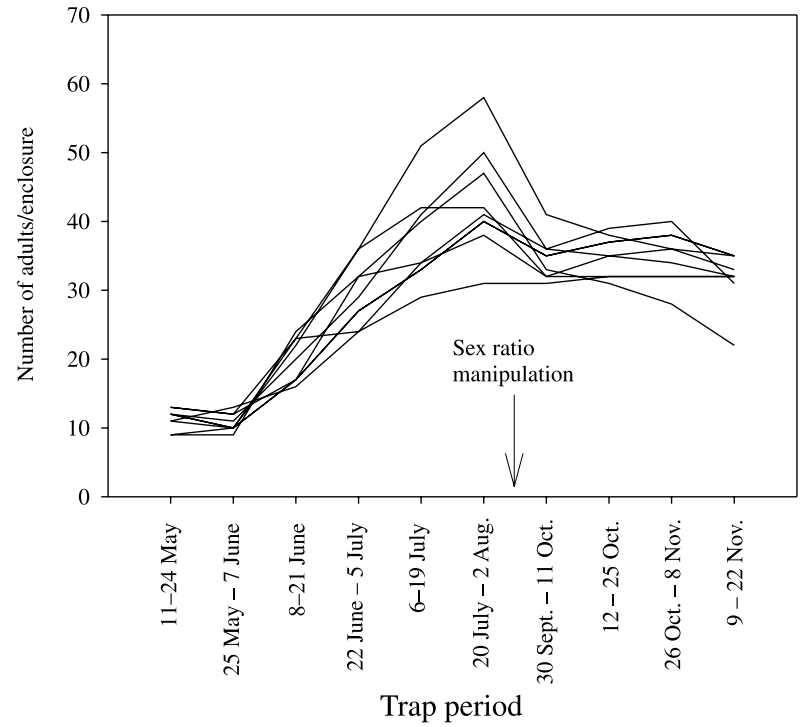

Wolff et al. (1994) demonstrated that $>80 \%$ of gray-tailed voles were captured in 4 days of trapping. The date of conception was estimated for each recruit by assuming that pups gain about 1 g/day from birth until capture and backcalculating a gestation period of 21 days. Population sex ratio was represented as proportion of males (number of males/number of males + number of females) and week of conception was represented as number of weeks after first trap week (first trap week = week 1).

We captured a total of 1047 recruits throughout the study period (May-December). However, data from mid-August to mid-September were excluded because we were unable to assign an enclosure to recruits that were conceived during that time and captured after population manipulation in September. Therefore, data from 960 recruits were used in the analyses. In addition, data from 2 weeks in August were not used in calculating overall recruit sex ratios because $<10$ recruits were captured in all enclosures combined during that time.

\section{Statistical analyses}

We tested for effects of adult sex ratio at week of conception (PSR), adult density at week of conception (LRC), week of conception (FCA), and enclosure (i.e., population) on recruit sex ratios. Generalized linear mixed models (GLMMs) were used with logit response and binomial data distribution (Krackow and Tkadlec 2001). Mixed models allow the introduction of random coefficients into a model (see Allison 1999; Krackow and Tkadlec 2001). Individual recruits were considered the experimental units, and enclosure was considered to be a random effect to account for variation among populations. The random effect of population was separable from the other independent variables because the populations were resampled each week; thus, any population differences that affect sex ratios were not treated as merely density effects (Krackow and Tkadlec 2001). Our model included the fixed-effect variables of week after ex-
Fig. 2. Sex ratio (proportion of males) in the adult population of gray-tailed voles measured at 2-week intervals in eight enclosures from spring through autumn at Hyslop Farm, Oregon, 1997.

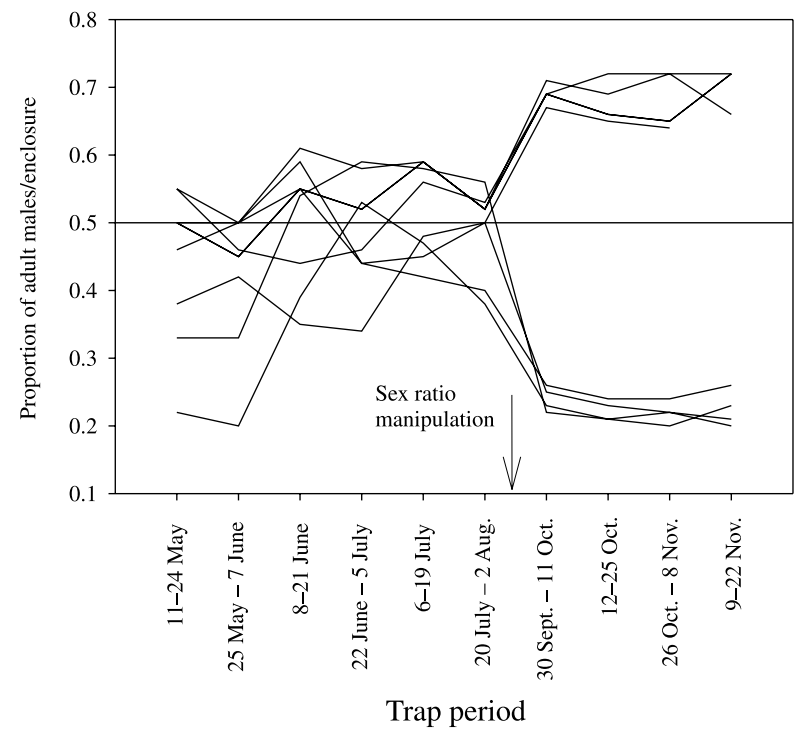

perimental onset, adult sex ratio, adult density, and the interaction between adult sex ratio and density, at the time of conception for each recruit, as well as the random covariance parameter of enclosure. The GLMM analyses were carried out using the GLIMMIX macro and PROC MIXED of the SAS statistical package (Littell et al. 1999; SAS Institute, Inc. 1999). Type 3 tests of fixed effects were calculated, which treat each effect as if entered last in the model (i.e., the tests are invariant to the ordering of the effects in the model). The response variable was the log odds of a recruit being male (male $=1$, female $=0)$. Variables were centered prior to analyses. Centering the variables means subtracting the variable's mean from each case's value on that variable. Centering reduces multicollinearity between the predictors and the interaction term and allows more meaningful interpretations of the regression coefficients.

\section{Results}

High densities of males were 18-25 per enclosure and low densities of females were 9-12. Low densities of males were seven to nine per enclosure and high densities of females were 24-32. Adult population density varied by enclosure but increased by a range of $238 \%-644 \%$ from spring to late summer (Fig. 1). Mean adult population sex ratio for all enclosures for all weeks from spring to late summer was $48 \%$ male (range $=20 \%-61 \%$ ) (Fig. 2). Mean population size in all of the enclosures throughout the fall sex-ratio treatment was 34 adults (range $=28-41$ adults) (Fig. 1). Adult population sex ratios during the autumn sex-ratio treatments averaged $69 \%$ male in the male-skewed enclosures (range = $64 \%-72 \%$ ) and $23 \%$ male in the female-skewed enclosures (range $=20 \%-26 \%)$, indicating that relatively strong sexratio skews persisted throughout the treatment period (Fig. 2).

We trapped only six to eight adult females per enclosure ( 35 females/ha) at the beginning of the study period. At low densities, female home ranges had minimal overlap with 
neighbors and many trap stations were not utilized, indicating that vacant space was available for colonization by young females (Bond and Wolff 1999). Densities increased from five to eight adults of each sex (50-80 adults/ha) in spring to 29-51 adults of each sex (290-500 adults/ha) by midsummer. As densities increased, mean home-range sizes of adult males and females decreased significantly (from 257.0 to $66.1 \mathrm{~m}^{2}$ for males and from 91.8 to $29.1 \mathrm{~m}^{2}$ for females), and overlap of trap stations by adult females increased from $1.58 \pm 1.58$ (mean $\pm \mathrm{SE}$ ) to $2.71 \pm 2.01$ (Bond and Wolff 1999). At these higher densities, female home ranges overlapped considerably, suggesting greater competition for breeding space.

Recruitment sex ratios differed throughout the study pe$\operatorname{riod}\left(F_{[1,955]}=6.64, p<0.01\right)$. However, we found no significant effect of adult population density $\left(F_{[1,955]}=0.01, p>\right.$ $0.9)$, percentage of adult males $\left(F_{[1,955]}=1.86, p>0.17\right)$, or their interaction $\left(F_{[1,955]}=0.00, p>0.96\right)$ on recruitment sex ratios. Overall mean sex ratios of recruits were $42 \%$ males in spring (May-June) $(n=217), 45 \%$ in summer (July) $(n=$ $145)$, and $59 \%$ in autumn (September-November) $(n=583)$, indicating overproduction of females in spring and males in autumn (Fig. 3).

\section{Discussion}

Our data did not support the prediction of the PSR hypothesis. Theoretically, sex-specific mortality over time and localized mating within a population might create selection pressures that lead to the ability to counterbalance biased adult sex ratios under specific circumstances (e.g., Werren and Charnov 1978). If a consistent pattern of environmental perturbation causes significant localized skews of adult sex ratio (Clutton-Brock and Iason 1986), skews in consecutive breeding seasons are correlated (Bensch et al. 1999), and migration between subpopulations does not negate the effect of the skew. In that event, selection might favor sex-ratio adjustment in subpopulations with overlapping generations. But such a strategy must be frequency dependent, limiting sex-ratio adjustment so that adult sex ratios are not skewed too far in the opposite direction (Bensch et al. 1999), and would require strong sex-specific mortality. Perhaps because of the strictness of such requirements and the lack of strong, consistent sex-ratio skews in natural populations, offspring sex-ratio skews in response to biased adult sex ratios have rarely been documented in higher vertebrates (Clutton-Brock and Iason 1986; Lummaa et al. 1998; Krackow 2002) and directions of skews have not been consistent (see McClure 1981; Sikes 1995, 1996). For example, whereas female mouse lemurs, Microcebus murinus, produce relatively more male offspring when exposed to urinary cues of adult females (Perret 1990, 1996), house mouse mothers produced relatively more daughters when exposed to urine odors of eight unfamiliar adult females before mating (Drickamer 1999). These and other examples suggest that slight sexratio trends may be affected more by population dynamic events, season, or maternal condition than by facultative sexratio adjustment (Krackow 1995). Thus, our failure to support a PSR hypothesis is not surprising, especially for a
Fig. 3. Proportion of new gray-tailed vole recruits (with $95 \%$ confidence interval) that were male measured at 2-week intervals in eight enclosures from spring through autumn at Hyslop Farm, Oregon, 1997.

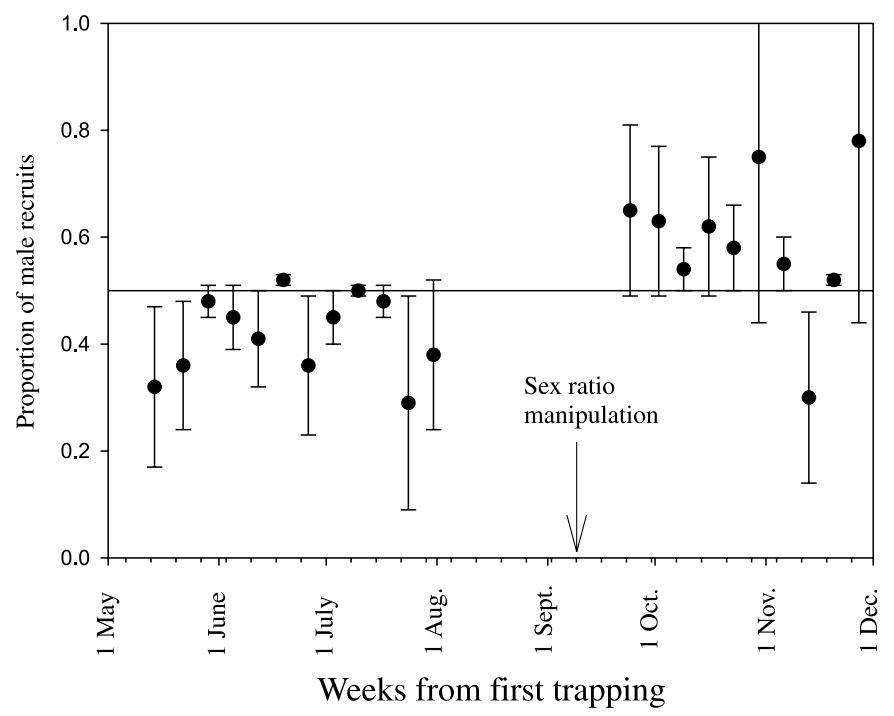

short-lived species that has evolved in highly fluctuating populations and environmental stochasticity.

Similarly, we found no support for the LRC hypothesis at high population densities, even though densities in our study reached 290-500 voles/ha, or 29-51 adults of each sex per enclosure. Most peak densities of naturally occurring cycling microtine species are 200-300 voles/ha (Taitt and Krebs 1985), and previous studies of gray-tailed voles in these enclosures showed that density-dependent effects on adult home-range size and juvenile recruitment occurred at densities of about 300 voles/ha (Wolff et al. 1994; Wolff and Schauber 1996; Bond and Wolff 1999). Recruitment, survival, and sexual maturation of juvenile females were negatively affected at densities of 100 females/ha (Wolff et al. 2002). Thus, we assumed that space for daughters to establish territories might be limiting at higher densities in our study, yet we did not find a bias towards male recruits. Others have similarly failed to find a sex-ratio bias in recruitment in response to density (e.g., Lambin 1994; Wolff et al. 2002). We did not quantify food or space availability during this study but had no indication that food was limited or that it affected reproduction (also see Bond and Wolff 1999; Wolff et al. 2002).

Our data supported the predictions of the FCA hypothesis in that we observed female-biased recruitment sex ratios in spring and male-biased recruitment sex ratios at the end of the breeding season. The female-biased recruitment that we observed in the spring is also consistent with the LRC hypothesis at low densities. However, we had the same low densities of adult females in autumn and yet sex ratios favored males. Since enclosures with low densities of females had unoccupied space available for colonization in spring and autumn, we should expect overproduction of females during both seasons; however, we did not see this. Thus, the most parsimonious explanation for greater production of daughters in spring is a seasonal rather than a local resource 
competition effect. Female-biased sex ratios were documented in spring litters of Townsend's voles (Lambin 1994) and male-biased sex ratios were observed in autumn litters of meadow voles (McShea and Madison 1986). Such sexratio adjustment may be adaptive in that juvenile male meadow voles were most likely to enter the breeding population if they were born late in the year and delay maturation until the following spring (Boonstra 1989). In contrast, female voles typically breed in their year of birth, often at a young age, and when their mothers are still alive (Boonstra 1989; Lambin 1994). In addition, over-winter survival of late-summer and autumn-born male gray-tailed voles and meadow voles was higher than that of females, possibly because males are more tolerated within winter communal groups (Madison et al. 1984; Brunkal 1996). We did not have direct evidence to explain the biological mechanism for the recruitment sex-ratio bias; however, because differential mortality after the period of parental care does not alter the sex ratio at birth (Leigh 1970), it is possible that after giving birth, mothers were selectively allocating energy towards their daughters in the spring and their sons in the autumn (McClure 1981; McShea and Madison 1986). Whatever the mechanism involved, this pattern of differential sex allocation suggests that females might benefit from greater investment in daughters in spring and sons in fall.

In conclusion, our experiment revealed significant seasonal sex-ratio adjustment in gray-tailed voles, similar to the findings of studies with other species of rodents (McShea and Madison 1986; Boonstra 1989; Zuleta and Bilenca 1992; Lambin 1994; Wright et al. 1995). Gray-tailed voles might not have the ability or there might be no selective advantage for adjusting the sex ratio in response to population sex ratio or local resource competition because skews in population sex ratios are not predictable over time and critical resources may not be limited at high densities. Future research on facultative sex-ratio adjustment should focus on determining if any fitness advantage occurs for sons or daughters born at different densities, seasons, and population sex ratios.

\section{Acknowlegements}

This work was supported by the National Science Foundation (No. 9508319), Environmental Protection Agency, the Northwest Scientific Association, and Gamma Sigma Delta (the Honor Society of Agriculture). We thank T. Caslin, C. Dalton, B. Skillen, K. Walker, and G. Wang for their assistance in the field, and D. Lee and S. Thomas for valuable input on the manuscript. This is manuscript No. 11422 of the Oregon Agricultural Experiment Station. This experiment complied with all current U.S. laws.

\section{References}

Allison, P.D. 1999. Logistic regression using the SAS system. SAS Institute, Inc., Cary, N.C.

Bensch, S., Westerdahl, H., Hansson, B., and Hasselquist, D. 1999. Do females adjust the sex of their offspring in relation to the breeding sex ratio? J. Evol. Biol. 12: 1104-1109.

Bond, M.L., and Wolff, J.O. 1999. Does access to females or competition among males limit home-range size of males in a promiscuous rodent? J. Mammal. 80: 1243-1250.
Boonstra, R. 1989. Life history variation in maturation in a fluctuating meadow vole population (Microtus pennsylvanicus). Oikos, 54: 265-274.

Brunkal, H. 1996. Overwinter demography of the gray-tailed vole (Microtus canicaudus) in fragmented and continuous habitats. M.S. thesis, Oregon State University, Corvallis.

Clark, A.B. 1978. Sex ratio and local resource competition in a prosimian primate. Science (Wash., D.C.), 201: 163-164.

Clutton-Brock, T.H., and Iason, G.R. 1986. Sex ratio variation in mammals. Q. Rev. Biol. 51: 339-369.

Dalton, C.D. 2000. Effects of female kin groups on reproduction and demography in the gray-tailed vole, Microtus canicaudus. Oikos, 90: 153-159.

Drickamer, L.C. 1999. Pregnancy in female house mice exposed to urinary chemosignals from other females. J. Reprod. Fertil. 115: 233-241.

Fisher, R.A. 1930. The genetical theory of natural selection. Oxford University Press, Oxford, U.K.

Frank, S.A. 1990. Sex allocation theory for birds and mammals. Annu. Rev. Ecol. Syst. 21: 13-55.

Hamilton, W.D. 1967. Extraordinary sex ratios. Science (Wash., D.C.), 156: 477-488.

Hewison, A.J., and Gaillard, J.M. 1996. Birth sex ratios and local resource competition in roe deer, Capreolus capreolus. Behav. Ecol. Sociobiol. 7: 461-446.

Krackow, S. 1995. The developmental asynchrony hypothesis for sex ratio manipulation. J. Theor. Biol. 176: 273-280.

Krackow, S. 2002. Why parental sex ratio manipulation is rare in higher vertebrates. Ethology, 108: 1041-1056.

Krackow, S., and Tkadlec, E. 2001. Analysis of brood sex ratios: implications of offspring clustering. Behav. Ecol. Sociobiol. 50: 293-301.

Lambin, X. 1994. Sex ratio variation in relation to female philopatry in Townsend's voles. J. Anim. Ecol. 63: 945-953.

Leigh, E.G.J. 1970. Sex ratio and differential mortality between the sexes. Am. Nat. 104: 205-210.

Leimar, O. 1996. Life history analysis of the Trivers and Willard sex ratio problem. Behav. Ecol. 7: 316-325.

Littell, R.C., Milliken, G.A., Stroup, W.W., and Wolfinger, R.D. 1999. SAS system for mixed models. SAS Institute, Inc., Cary, N.C.

Lummaa, V., Merilä, J., and Kause, A. 1998. Adaptive sex ratio variation in pre-industrial human (Homo sapiens) populations? Proc. R. Soc. Lond. B Biol. Sci. 265: 563-568.

Madison, D.M., Fitzgerald, R.W., and McShea, W.J. 1984. Dynamics of social nesting in overwintering meadow voles (Microtus pennsylvanicus): possible consequences for population cycling. Behav. Ecol. Sociobiol. 15: 9-17.

McClure, P.A. 1981. Sex-biased litter reduction in food-restricted wood rats (Neotoma floridana). Science (Wash., D.C.), 211: 1059-1060.

McShea, W.J., and Madison, D.M. 1986. Sex ratio shifts within litters of meadow voles (Microtus pennsylvanicus). Behav. Ecol. Sociobiol. 18: 431-436.

Myers, J.H., and Krebs, C.J. 1971. Sex ratios in open and enclosed vole populations: demographic implications. Am. Nat. 105: 325-344.

Olsson, M., and Shine, R. 2001. Facultative sex allocation in snow skin lizards (Niveoscincus microlepidotus). J. Evol. Biol. 14: 120-128.

Packer, C., and Pusey, A.E. 1987. Intrasexual cooperation and the sex ratio in African lions. Am. Nat. 130: 636-642. 
Pen, I., and Weissing, F.J. 2002. Optimal sex allocation: steps towards a mechanistic theory. In Sex ratios: concepts and research methods. Edited by I.C.W. Hardy. Cambridge University Press, Cambridge, U.K. pp. 26-45.

Pen, I., Weissing, F.J., and Daan, S. 1999. Seasonal sex ratio trend in the European Kestrel: an ESS analysis. Am. Nat. 153: $384-$ 397.

Perret, M. 1990. Influence of social factors on sex ratio at birth, maternal investment and young survival in a prosimian primate. Behav. Ecol. Sociobiol. 27: 447-454.

Perret, M. 1996. Manipulation of sex ratio at birth by urinary cues in a prosimian primate. Behav. Ecol. Sociobiol. 38: 259-266.

Ranta, E., Lummaa, V., Kaitala, V., and Merila, J. 2000. Spatial dynamics of adaptive sex ratios. Ecol. Lett. 3: 30-34.

Sadler, D.L. 1981. An experimental confirmation of R.A. Fisher's theory of the sex ratio. Am. J. Phys. Anthropol. 54: 272.

Saitoh, T. 1990. Lifetime reproductive success in reproductively suppressed female voles. Res. Popul. Ecol. 32: 391-406.

SAS Institute, Inc. 1999. SAS, version 7. SAS Institute, Inc., Cary, N.C.

Sikes, R.S. 1995. Maternal response to resource limitation in eastern woodrats. Anim. Behav. 49: 1551-1558.

Sikes, R.S. 1996. Tactics of maternal investment of grasshopper mice in response to postnatal restriction of food. J. Mammal. 77: 1092-1101.

Silk, J.B. 1983. Local resource competition and facultative adjustment of sex ratios in relation to competitive abilities. Am. Nat. 121: $56-63$.
Taitt, M.J., and Krebs, C.J. 1985. Population dynamics and cycles. In Biology of New World Microtus. Edited by R.H. Tamarin. Allen Press, Lawrence, Kans. pp. 567-620.

Trivers, R.L., and Willard, D.E. 1973. Natural selection of parental ability to vary the sex ratio of offspring. Science (Wash., D.C.), 179: 90-91.

van Schaik, C., and Hrdy, S. 1991. Intensity of local resource competition shapes the relationship between maternal rank and sex ratios at birth in cercopithecine primates. Am. Nat. 138: 15551562.

Werren, J.H., and Charnov, E.L. 1978. Facultative sex ratio and population dynamics. Nature (Lond.), 272: 349-350.

Wolff, J.O., and Schauber, E. 1996. Space use and juvenile recrutiment in gray-tailed voles in response to intruder pressure and food abundance. Acta Theriol. 41: 35-43.

Wolff, J.O., Edge, W.D., and Bentley, R. 1994. Reproductive and behavioral biology of the gray-tailed vole. J. Mammal. 75: 873879.

Wolff, J.O., Edge, W.D., and Wang, G. 2002. Effects of adult sex ratios on recruitment of juvenile gray-tailed voles, Microtus canicaudus. J. Mammal. 83: 947-956.

Wright, D.D., Ryser, J.T., and Kiltie, R.A. 1995. First cohort advantage hypothesis - a new twist on facultative sex ratio adjustment. Am. Nat. 145: 133-145.

Zuleta, G.A., and Bilenca, D.N. 1992. Seasonal shifts within juvenile recruit sex ratio of Pampas mice (Akodon azarae). J. Zool. (Lond.), 227: 397-404. 